\title{
ZNANJE, STAV I PRAKSA ZDRAVSTVENIH DJELATNIKA - CIJEPLJENJU ZDRAVSTVENIH DJELATNIKA PROTIV INFLUENCE U SVEUČILIŠNOJ KLINIČKOJ BOLNICI MOSTAR
}

\author{
${ }^{1}$ Ivan Mimica, ${ }^{2}$ Olga Šegvić, ${ }^{13}$ Jadranka Nikolić, ${ }^{1}$ Ivan Vasilj ${ }^{4}{ }^{3}$ Svjetlana Grgić \\ ${ }^{1}$ Medicinski fakultet Sveučilište u Mostaru, Bosna i Hercegovina \\ ${ }^{2}$ Dom zdravlja "dr. Ante Franulovic" Vela Luka, Hrvatska \\ ${ }^{3}$ Klinika za infektivne bolesti Sveučilišna klinička bolnica Mostar, Bosna i Hercegovina \\ ${ }^{4}$ Fakultet zdravstvenih studija Sveučilište u Mostaru, Bosna i Hercegovina
}

Rad je primljen: 4.2.2015.

Rad je revidiran: 4.3.2015.

Rad je prihvaćen: 29.4.2015.

\section{SAŽETAK}

UVOD: Cijepljenjem zdravstvenog osoblja može se smanjiti prijenos infekcije na bolesnike koji nose visok rizik od razvoja komplikacija i broj smrti povezanih s influencom. Stoga cilj ovog istraživanja je bio ispitati znanje, stav i praksu zdravstvenih djelatnika u Sveučilišnoj kliničkoj bolnici Mostar o cijepljenju istih protiv influence.

ISPITANICI I METODE: Ispitanici u ovom istraživanju bili su liječnici i medicinske sestre zaposleni na klinikama za neurologiju, dječje bolesti, infektivne bolesti, Odjelu za plućne bolesti, te Centru za urgentnu medicinu SKB Mostar. Korišten je upitnik za ispitivanje znanja, stava i prakse zdravstvenih djelatnika o cijepljenju zdravstvenih djelatnika protiv influence. REZULTATI: Većinu očekivanih reakcija nakon cijepljenja, komplikacija influence i pitanje sigurnosti cijepiva doktori medicine su značajno češće znali od medicinskih sestara. Većinu mogućih komplikacija nakon cijepljenja i indikacije za cijepljenje protiv influence češće su znali doktori medicine zaposleni na Klinici za infektologiju od ostalih kolega. Medicinske sestre značajno češće mislile da svi zdravstveni djelatnici trebaju biti obvezno cijepljeni protiv influence za razliku od liječnika. Za razliku od kolega liječnici Klinike za infektologiju značajno su češće smatrali da svi zdravstveni djelatnici trebaju biti obvezno cijepljeni protiv influence. Liječnici značajno su češće savjetovali i promovirali cijepljenje protiv influence od medicinskih sestara.

ZAKLJUČAK: Prosječna procijepljenost protiv influence zdravstvenih djelatnika u Sveučilišnoj kliničkoj bolnici Mostar je bila niska, njihovi stavovi negativni, a znanje o influenci i cijepljenju protiv influence nedovoljno.

Ključne riječi: Influenca, znanje, stav, cijepljenje, zdravstveni djelatnici, doktori medicine, medicinske sestre

Osoba za razmjenu informacija:

Mr. sc. Svetlana Grgic,

Klinika za infektivne bolesti

Sveučilišna klinička bolnica Mostar

svjetlanag@gmail.com

\section{UVOD}

Influenca je akutna infektivna bolest dišnoga sustava koju uzrokuju virusi influence A, B i C praćena brojnim raznovrsnim poremećajima organskih funkcija i čestim sekundarnim bakterijskim infekcijama (1-4). Komplikacije su najčešće u dišnom sustavu, osobito upale pluća, ali mogu biti zahvaćeni i ostali organi. Komplikacije izvan dišnog sustava, kao miozitis, rabdomioliza, encefalitis, mijelitis, Guillain-Barréov sindrom, mioperikarditis itd. pripisuju se izravnom djelovanju virusa. Jedna od vrlo važnih komplikacija influence jest i Reyeov sindrom, a susreće se samo u djece. Teži klinički tijek i veći broj težih komplikacija u tijeku influence pojavljuju se u mlađe djece, djece $i$ adolescenata na terapiji salicilatima, trudnica, 
pretilih osoba, starijih osoba, bolesnika s kroničnim bolestima te imunokompromitiranih osoba. Veća prevalencija stanja koja su visokorizična za influencu, kao što su kardiovaskularne i cerebrovaskularne bolesti važan su čimbenik koji dovodi do povećanja broja hospitalizacija i smrti zbog influence $(5,6)$.

Klinička se dijagnoza potvrđuje specifičnim virološkim pretragama: izolacijom virusa, utvrđivanjem porasta titra specifičnih protutijela, dokazom antigena ili strukture virusne nukleinske kiseline. Osnovno je liječenje influence simptomatsko. To uključuje mirovanje, nadoknadu tekućine i elektrolita peroralno ili infuzijama, uzimanje antipiretika i antitusika, po potrebi primjenu kisika itd. Primjena antivirusnih lijekova indicirana je u liječenju primarne virusne pneumonije i u prevenciji komplikacija u osoba s visokim rizikom. Antibiotici se primjenjuju samo pri dokazanim ili vrlo vjerojatnim bakterijskim infekcijama (1).

Cijepljenje je najbolji način sprečavanja zaraze virusom influence, kao i razvoja bolesti i njezinih komplikacija (7). Cijepljenje se preporučuje osobama pod povećanim rizikom od razvoja komplikacija gripe, osobama kojima bi gripa mogla ozbiljno pogoršati osnovnu bolest i zdravstvenim radnicima koji su u kontaktu s osjetljivim bolesnicima (8). Cjepiva protiv gripe ne pružaju $100 \%$-tnu zaštitu cijepljenim osobama i kod dijela cijepljenih osoba mogu izazvati nuspojave, ali očekivana korist od primjene cjepiva uvelike nadilazi potencijalni rizik (8). Cijepljenje sprječava influencu u 70-90 \% cijepljenih prethodno zdravih odraslih osoba (7).

\section{Cijepljenje zdravstvenih djelatnika}

Cijepljenjem zdravstvenog osoblja može se smanjiti prijenos infekcije na bolesnike koji nose visok rizik od razvoja komplikacija, te se može smanjiti broj smrti povezanih s influencom $(7,9)$. Visoke stope procijepljenosti zdravstvenog osoblja protiv influence posredno pružaju zaštitu i onim bolesnicima koji iz bilo kojeg razloga nisu cijepljeni, a ujedno smanjuju stopu bolovanja i izostanak bolničkog osoblja s posla tijekom vrlo osjetljivog razdoblja epidemije kada su zahtjevi za zdravstvenom skrbi povećani $(7,10)$. Kako bi se spriječilo širenje influence u zdravstvenim ustanovama, potrebno je postići procijepljenost zdravstvenih djelatnika veću od 80 \% (7). Procijepljenost protiv influence među zdravstvenim djelatnicima je neprihvatljivo niska (11). Glavni razlozi zbog kojih zdravstveni djelatnici odbijaju cijepljenje protiv influence su strah od nuspojava te nizak stupanj zabrinutosti zbog influence (7). Zbog toga je potrebno osigurati da zdravstveni djelatnici budu informirani o cijepljenju protiv influence i koliko je važno da se cijepe $(12,13)$. Odbijanje cijepljenja povećava ne samo osobni rizik od oboljevanja, nego povećava i rizik za čitavu zajednicu (14). Stoga bi visoki stupanj procijepljenosti među zdravstvenim djelatnicima koristio pacijentima, samim zdravstvenim djelatnicima, njihovim obiteljima i zajednici u kojoj rade i žive (15).

Cilj ovog istraživanja je bio ispitati znanje, stav i praksu zdravstvenih djelatnika u Sveučilišnoj kliničkoj bolnici Mostar o cijepljenju zdravstvenih djelatnika protiv influence.

\section{ISPITANICI I METODE Ispitanici}

Ispitanici u ovom istraživanju bili su liječnici i medicinske sestre zaposleni na Klinci za neurologiju, Klinici za dječje bolesti, Klinici za infektivne bolesti, Odjelu za plućne bolesti i tuberkulozu te Centru za urgentnu medicinu i hitne prijeme. Zdravstveni djelatnici Klinike za neurologiju, Klinike za dječje bolesti, Klinike za infektivne bolesti, Odjela za plućne bolesti i tuberkulozu najčešće dolaze u kontakt s pacijentima koji većinom pripadaju skupini bolesnika s povećanim rizikom od razvoja komplikacija i smrtnih slučajeva vezanih uz influencu, pa su zbog toga i izabrana ciljna skupina ispitivanja. Centar za urgentnu medicinu i hitne prijeme je mjesto prvog kontakta velikog broja pacijenata prije njihove hospitalizacije.

U veljači, ožujku i travnju 2014. godine podaci su prikupljeni dobrovoljnim, anonimnim ispunjavanjem upitnika za ispitivanje znanja, stava i prakse zdravstvenih djelatnika o cijepljenju zdravstvenih djelatnika protiv influence. 


\section{Metode}

U istraživanju je korišten posebno kreiran upitnik za ispitivanje znanja, stava i prakse zdravstvenih djelatnika o cijepljenju zdravstvenih djelatnika protiv influence. Upitnik sadrži minimalne setove pitanja koja omogućavaju uvid u: a) osnovne podatke o zdravstvenim djelatnicima, b) znanje, c) stav i d) praksu djelatnika o cijepljenju protiv influence.

a) Osnovni podaci o zdravstvenim djelatnicima procijenili su se na osnovu pitanja koja se odnose na demografske karakteristike ispitanika: starost, spol, zanimanje, radno mjesto i radno iskustvo u struci.

b) Znanje se procijenilo na osnovu pitanja o indikacijama za cijepljenje protiv influence, komplikacijama i nuspojavama cijepljenja.

c) Stav se procijenio na osnovu pitanja o sigurnosti cjepiva protiv influence koje se koristi u Federaciji Bosne i Hercegovine, jesu li po njihovom mišljenju pacijenti i zdravstveni djelatnici dovoljno educirani i informirani o cjepivu protiv influence, te smatraju li obveznim cijepljenje protiv influence svih zdravstvenih djelatnika.

d) Praksa se procijenila na osnovu pitanja o vlastitom iskustvu s cijepljenjem protiv influence te ukoliko nikad nisu bili cijepljeni protiv influence definirati razloge za tu praksu.

\section{Statistička analiza}

U statističkoj obradi podataka, distribucija kontinuiranih varijabli testirana je Kolmogorov-Smirnovim testom, a za prikaz njihove srednje vrijednosti i mjere raspršenja korišteni su medijan i interkvartilni raspon, zbog distribucije koja je značajno odstupala od normalne. Za prikaz nominalnih varijabli korišteni su frekvencija i postotak. Za usporedbu nominalnih varijabli korišten je hi-kvadrat test, a pri manjku očekivane frekvencije Fisherov egzaktni test. Razlike između skupina bile su prihvaćene kao statistički značajne za $p<0,05$ Vrijednosti $p$ koje se nisu mogle iskazati do najviše tri decimalna mjesta, prikazane su kao $\mathrm{p}<0,001$. Za statističku analizu dobivenih podataka rabljen je programski sustav SPSS for Windows (inačica 13.0, SPSS Inc, Chicago,
Illinois, SAD) i Microsoft Excell (inačica Office 2007, Microsoft Corporation, Redmond, WA, SAD).

\section{REZULTATI}

Istraživanje je provedeno na uzorku od 121 ispitanika, 52 ili 43,7\% liječnika i 67 ili 56,3\% medicinskih sestara. Među ispitanicima nema statistički značajne razlike prema zanimanju (hi-kvadrat test $=1,891$; $\mathrm{p}=0,169)$. Ukupna srednja dob ispitanika bila je 36,00 [22,00] godina. Najmlađi ispitanik imao je 21, a najstariji 62 godine. Ukupna srednja dob ispitivanih doktora medicine bila je 32,00 [13,50], a medicinskih sestara 42,50 [22,75]. Najmlađi liječnik je imao 26, a najstariji 60 godina. Najmlađa medicinska sestra je imala 21, a najstarija 62 godine. Najveći udio ispitanika među liječnicima, njih 23 $(44,2 \%)$ bili su u dobnoj skupini od 30 do 39 godina, dok najčešća dobna skupina medicinskih sestara bila je 50 do 59 godina, zastupljena s njih 26 (38,8\%). Ispitanici su statistički značajno češće bili ženskog spola, ukupno 102 ili 85\% (hi-kvadrat test=58,800; $\mathrm{p}<0,001)$. U subuzorku liječnika 52/121, najbrojniji bili su pedijatri, njih $30,8 \%$, potom liječnici CUM-a $21,2 \%, 17,3 \%$ neurologa, te $15,4 \%$ infektologa i pulmologa. U subuzorku medicinskih sestara 67/121, najbrojnije bile su medicinske sestre zaposlene na pulmologiji, njih 28,4\%, neurologiji 23,9\%, CUM-u i infektologiji 16,4\%, te pedijatriji 14,9\% (slika 1).

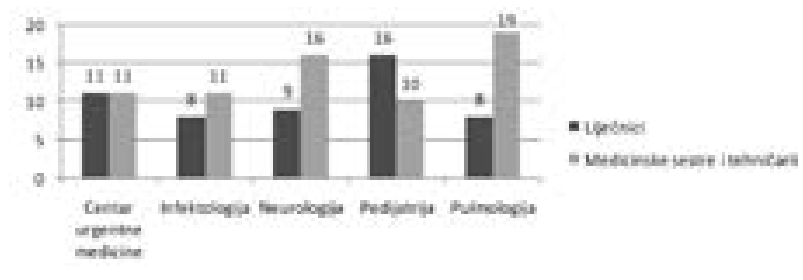

Slika 1. Prikaz raspodjele ispitanika u uzorku s obzirom na zanimanje i radno mjesto

Ukupni prosječni radni staž svih ispitanika bio je $10,50[20,25]$ godina, od toga liječnici su radili prosječno $6,00[10,50]$ godine, a medicinske sestre bile su prosječno dužeg radnog vijeka i to $15,00[23,00]$ godina. 
Mimica I, Šegvić O, Nikolić J, Vasilj I, Grgić S. Znanje, stav i praksa zdravstvenih djelatnika o cijepljenju zdravstvenih djelatnika protiv influence u Sveučilišnoj kliničkoj bolnici Mostar. Zdravstveni glasnik. 2015;1:51-60

\section{Znanje zdravstvenih djelatnika o cijepljenju protiv influence}

Liječnici su statistički značajno češće znali od medicinskih sestara da su povišena temperatura, glavobolja, umor, bolovi u mišićima, alergijske reakcije, te Guillain-Barreov sindrom očekivane reakcije nakon cijepljenja protiv influence (tablica 1).

Tablica 1. Znanje zdravstvenih djelatnika o očekivanim reakcijama nakon cijepljenja

\begin{tabular}{lcccc}
\hline \multicolumn{5}{c}{ Broj ispitanika (\%) } \\
\hline $\begin{array}{l}\text { Očekivane reakcije nakon } \\
\text { cijepljenja }\end{array}$ & Liječnici & $\begin{array}{c}\text { Medicinske } \\
\text { sestre }\end{array}$ & $\begin{array}{c}\text { hi-kvadrat } \\
\text { test }\end{array}$ & p \\
\hline $\begin{array}{l}\text { povišena temperatura } \\
\text { glavobolja, umor, bolovi u }\end{array}$ & $50(96,2)$ & $56(83,6)$ & 4,76 & 0,029 \\
mišícima & $30(44,8)$ & 12,49 & $<0,001$ \\
$\begin{array}{l}\text { alergiijke reakcije } \\
\text { Guillain-Barreov sindrom }\end{array}$ & $33(92,3)$ & $44(65,7)$ & 11,84 & 0,001 \\
\hline
\end{tabular}

Statistički su značajno medicinske sestre zaposlene u Klinici za infektologiju u odnosu na ostale kolegice češće znale očekivane reakcije (glavobolja, umor, bolovi u mišićima) nakon cijepljenja protiv influence (hi-kvadrat test $=18,47 ; \mathrm{p}=0,001$ ). Zaposlenici Klinike za infektologiju su statistički značajno češće znali da su indikacije za cijepljenje protiv influence osobe $\geq 6$ mjeseci života ukoliko ne postoje kontraindikacije u odnosu na ostale kolege (hi-kvadrat test=12,60; $\mathrm{p}=0,013$ ) (slika 2).

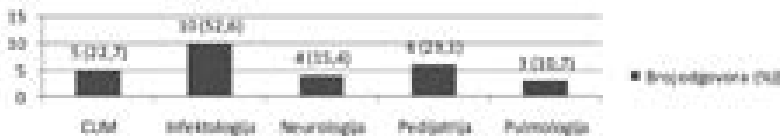

Slika 2. Prikaz odgovora „osobe $\geq 6$ mjeseci života ako ne postoje kontraindikacije" ispitanika u uzorku na pitanje „Terapijske indikacije za cijepljenje protiv influence:“ s obzirom na mjesto rada

U podjednakom omjeru, liječnici i medicinske sestre su poznavali najčešću komplikaciju influence, virusnu ili bakterijsku pneumoniju. Virusnu pneumoniju kao komplikaciju influence navelo je 46 (88,5 \%) liječnika i 58 (86,6 \%) medicinskih sestara, a bakterijsku pneumoniju $36(69,2 \%)$ liječnika te 42 $(62,7 \%)$ medicinske sestre (tablica 2$)$.
Tablica 2. Znanje zdravstvenih djelatnika o komplikacijama influence

\begin{tabular}{lcccc}
\hline \multicolumn{5}{c}{ Broj ispitanika (\%) } \\
\hline Komplikacije influence & $\begin{array}{c}\text { Doktori } \\
\text { medicine }\end{array}$ & sestrinske & hi-kvadrat & test \\
& & p & \\
\hline otitis media, sinusitis & $37(71,2)$ & $14(20,9)$ & 30,20 & $<0,001$ \\
encefalopatija & $37(71,2)$ & $19(28,4)$ & 21,52 & $<0,001$ \\
akutna egzacerebacija & $27(51,9)$ & $8(11,9)$ & 22,54 & $<0,001$ \\
KOPB-a & & & & \\
Guillain-Barreov & $35(67,3)$ & $13(19,4)$ & 27,92 & $<0,001$ \\
sindrom & $11(21,2)$ & $4(6,0)$ & 6,13 & 0,013 \\
infarkt miokarda & $27(51,9)$ & $6(9,0)$ & 26,97 & $<0,001$ \\
reaktivni artritis & $24(46,2)$ & $11(16,4)$ & 12,47 & $<0,001$ \\
sepsa & $23(44,2)$ & $9(13,4)$ & 14,13 & $<0,001$ \\
Reyeov sindrom & & & & \\
\hline & & &
\end{tabular}

Komplikacije influence statistički su češće poznavali zaposlenici Klinike za infektologiju, njih 89,5\%, $\mathrm{u}$ odnosu na ostale (hi-kvadrat test $=26,03 ; \mathrm{p}<0,001$ ). Infarkt miokarda kao komplikacija influence najmanje je poznata zaposlenicima koji rade na CUM-u, njih 4,5 \% (Fischerov egzaktni test; $\mathrm{p}=0,009$ ). Zanimljivo je da su zaposlenici CUM-a, njih 50,0 \%, statistički češće znali od ostalih kolega kako je i sepsa vrlo važna (hi-kvadrat test $=14,64 ; \mathrm{p}=0,005)$ komplikacija influence (slika 3).

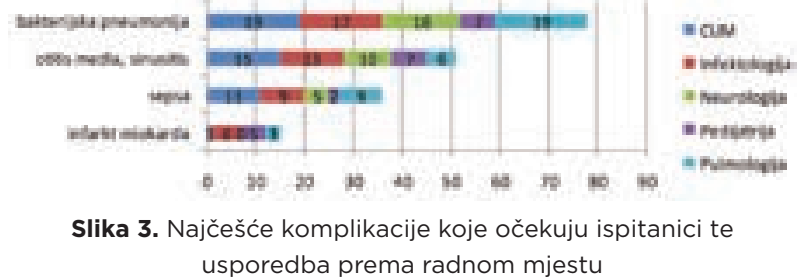

Liječnici Klinike za infektologiju i CUM-a statistički značajno su češće poznavali od ostalih kolega zaposlenih na drugim klinikama i odjelima bakterijska pneumoniju (Fischerov egzaktni test; $\mathrm{p}<0,001)$ kao vodeću komplikaciju influence. Svi liječnici Klinike za infektologiju statistički značajno bolje poznaju ostale komplikacije influence kao što su otitis media, sinusitis (Fischerov egzaktni test; $\mathrm{p}=0,020$ ), akutna egzacerebacija KOPB-a (Fischerov egzaktni test; $\mathrm{p}=0,001$ ), Guillain-Barreov sindrom (Fischerov egzaktni test; $\mathrm{p}=0,019$ ), te Reyeov sindrom (Fischerov egzaktni test; $\mathrm{p}<0,001$ ) komplikacije influence. Infarkt miokarda, liječnicima CUM-a, njih 9,1\%, bila je najmanje poznata komplikacija influence (Fischerov egzaktni test; $\mathrm{p}=0,009$ ). 
Liječnici Odjela pulmologije statistički značajno su češće znali od ostalih kolega da je reaktivni artritis $(87,5 \%)$ (Fischerov egzaktni test; $\mathrm{p}=0,028)$, te sepsa $(87,5 \%)$ (Fischerov egzaktni test; $p<0,001$ ) moguća komplikacije influence (slika 4).

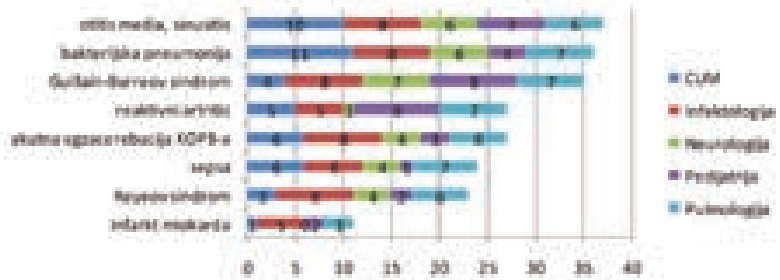

Slika 4. Najčešće komplikacije koje očekuju liječnici svih klinika/ odjela

Sve medicinske sestre zaposlene na Klinici za infektologiju i CUM-u statistički značajno su češće znale od ispitivanih medicinskih sestara zaposlenih na ostalim klinikama i odjelima da je virusna pneumonija (Fischerov egzaktni test; $\mathrm{p}=0,014$ ) komplikacija influence, a 45,5 \% otitis media, sinusitis (Fischerov egzaktni test; $\mathrm{p}=0,001$ ). Samo tri (30 \%) medicinske sestre zaposlene na Klinici za pedijatriju statistički značajno su češće znale od ostalih medicinskih sestara zaposlenih na ostalim klinikama i odjelima da je infarkt miokarda (Fischerov egzaktni test; $\mathrm{p}=0,005)$ komplikacija influence. Medicinske sestre zaposlene na CUM-u, njih 45,5\% statistički značajno su češće znale od ostalih da je i sepsa (Fischerov egzaktni test; $\mathrm{p}=0,015$ ) komplikacija influence (slika 5).

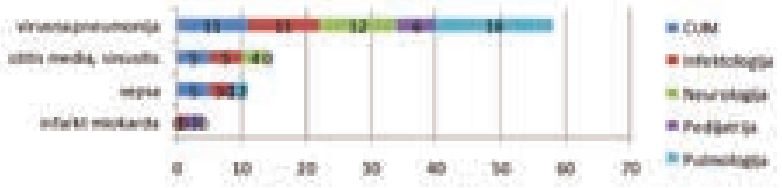

Slika 5. Najčešće komplikacije koje očekuju medicinske sestre svih Klinika i odjela

Djelatnici CUM-a, Klinike za infektologiju i Odjela za pulmologiju su statistički značajno češće odgovarali s „Da“ na pitanje „Zdravstveni djelatnici imaju veći rizik za profesionalnu izloženost i obolijevanje od influence te kao takvi su potencijalni prenositelji virusa na druge osobe koje borave u zdravstvenim ustanovama?" (hi-kvadrat test $=10,269 ;$ s.s. $=4$; $\mathrm{p}=0,036)$ (slika 6).

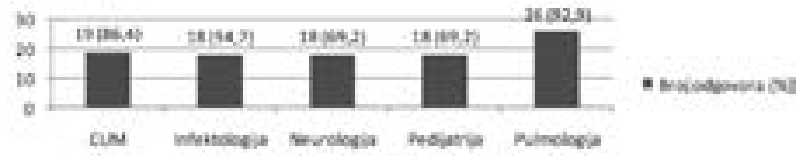

Slika 6. Prikaz odgovora „Da“ svih ispitanika u uzorku na pitanje: „Zdravstveni djelatnici imaju veći rizik za profesionalnu izloženost i obolijevanje od influence te kao takvi su potencijalni prenositelji virusa na druge osobe koje borave u zdravstvenim ustanovama?" s obzirom na mjesto rada

\section{Stavovi zdravstvenih djelatnika o cijepljenju zdravstvenih djelatnika protiv influence}

Liječnici su statistički značajno češće smatrali da je cjepivo protiv influence koje se koristi u FBiH sigurno i da njegova primjena predstavlja veću korist od rizika od medicinskih sestra, dok medicinske sestre statistički značajno nisu imale stav (tablica 3).

Tablica 3. Odgovori ispitanika na pitanje „Smatrate li da je cjepivo protiv influence koje se koristi u FBiH sigurno i da njegova primjena predstavlja veću korist od rizika"

\begin{tabular}{ccccc}
\hline \multicolumn{5}{c}{ Broj ispitanika (\%) } \\
\hline Odgovor & Liječnici & $\begin{array}{c}\text { Medicinska } \\
\text { sestra }\end{array}$ & $\begin{array}{c}\text { hi-kvadrat } \\
\text { test }\end{array}$ & $\mathrm{p}$ \\
\hline $\mathrm{Da}$ & $32(61,5)$ & $19(28,4)$ & 13,16 & $<0,001$ \\
$\mathrm{Ne}$ & $8(15,4)$ & $16(23,9)$ & 1,31 & 0,252 \\
Nemam stav & $12(23,1)$ & $32(47,8)$ & 7,66 & 0,006 \\
Ukupno & 52 & 67 & & \\
\hline
\end{tabular}

Zanimljivo je da medicinske sestre značajno više smatraju da svi zdravstveni djelatnici trebaju biti obvezno cijepljeni protiv influence (hi-kvadrat test $=3,94 ; \mathrm{p}=0,047$ ), dok liječnici smatraju kako svi zdravstveni djelatnici ne trebaju biti obvezno cijepljeni protiv influence (hi-kvadrat test $=6,00$; $\mathrm{p}=0,014)$ (slika 7).

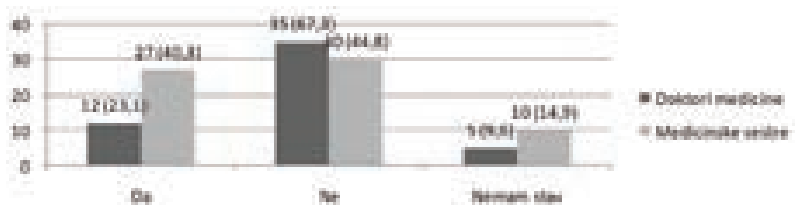

Slika 7. Prikaz odgovora liječnika i medicinskih sestara na pitanje „Smatrate li da svi zdravstveni djelatnici trebaju biti obvezno cijepljeni protiv influence?"

Liječnici Klinike za infektologiju statistički značajno su češće smatrali da svi zdravstveni djelatnici trebaju biti obvezno cijepljeni protiv influence za 
razliku od kolega koji rade na ostalim ispitivanim odjelima i klinikama (Fischerov egzaktni test; $\mathrm{p}<0,001)$ (slika 8).

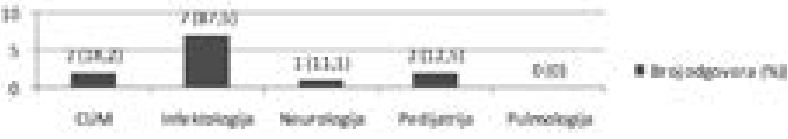

Slika 8. Prikaz odgovora „Da“ liječnika na pitanje „Smatrate li da svi zdravstveni djelatnici trebaju biti obvezno cijepljeni protiv influence?" s obzirom na mjesto rada

\section{Praksa cijepljenja zdravstvenih djelatnika}

Liječnici statistički značajno su češće savjetovali cijepljenje protiv influence od medicinskih sestara (hi-kvadrat test $=20,83 ; \mathrm{p}<0,001)$ ( slika 9).

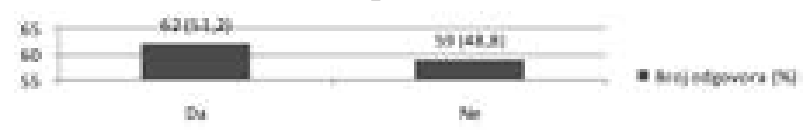

Slika 9. Prikaz odgovora svih ispitanika u uzorku na pitanje: „Jeste li savjetovali ikada do sada cijepljenje protiv influence?"

No, zanimljivo je da su medicinske sestre Klinike za neurologiju statistički značajno češće savjetovale cijepljenje protiv influence od medicinskih sestara na ostalim ispitivanim klinikama i odjelima (hi-kvadrat test $=12,65 ; \mathrm{p}=0,013)$ (slika 10).

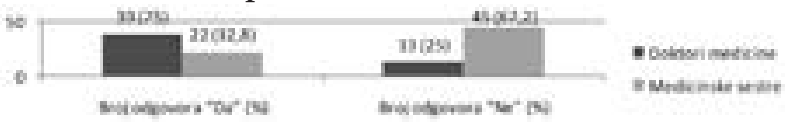

Slika 10. Prikaz odgovora liječnika i medicinskih sestara na pitanje „Jeste li savjetovali ikada do sada cijepljenje protiv influence?"

Liječnici su češće promovirali cijepljenje u odnosu na medicinske sestare (hi-kvadrat test $=6,76$; s.s. $=1 ; \mathrm{p}=0,009)($ slika 11$)$.

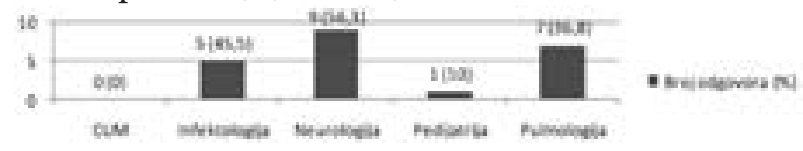

Slika 11. Prikaz odgovora „Da“ medicinskih sestara na pitanje: „Jeste li savjetovali ikada do sada cijepljenje protiv influence?" s obzirom na mjesto rada

Cijepljenje protiv influence za ovu sezonu proveli su samo svi liječnici Klinike za infektologiju u odnosu na ostale što je i statistički značajno (Fischerov egzaktni test; $\mathrm{p}<0,001)$ kao i medicinske sestre, njih $9(81,8$ \%) Klinike za infektologiju (Fischerov egzaktni test; $\mathrm{p}<0,001)$. Proteklih godina su se statistički značajno liječnici Klinike za infektologiju cijepili protiv influence za razliku od kolega ostalih ispitivanih klinika i odjela (Fischerov egzaktni test; $\mathrm{p}=0,011)$ (slika 12), kao i medicinske sestre Klinike za infektologiju (Fischerov egzaktni test; $\mathrm{p}=0,027$ ) (slika 13).

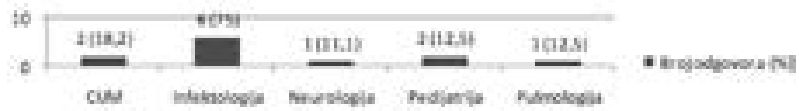

Slika 12. Prikaz odgovora „Da“ liječnici na pitanje: „Jeste li se ikad prije cijepili protiv influence?" s obzirom na mjesto rada

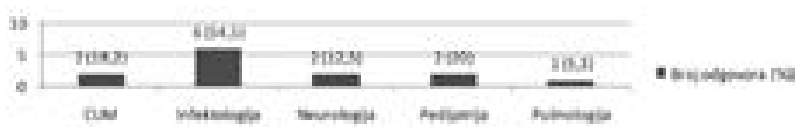

Slika 13. Prikaz odgovora „Da“ medicinskih sestara na pitanje: „Jeste li se ikad prije cijepili protiv influence?“ s obzirom na mjesto rada

Većina zdravstvenih djelatnika, njih 47 ili 43,5\% smatra kako ne spadaju u rizičnu skupinu za cijepljenje te se stoga nisu niti cijepili (slika 14).

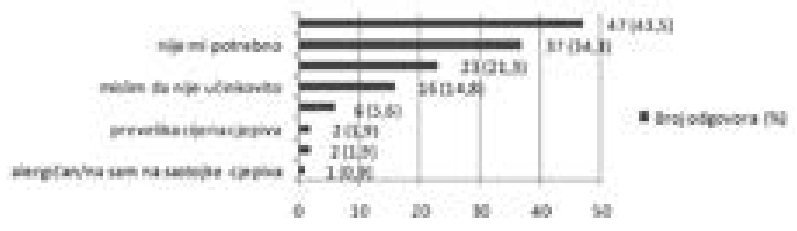

Slika 14. Razlozi za izbjegavanje cijepljenja zdravstvenih djelatnika

Najčešći razlog necijepljenja većina doktora medicine, njih 25 ili 55,6\% smatra da ne pripadanje u rizičnu skupinu te da im nije potrebno cijepljenje (slika 15).

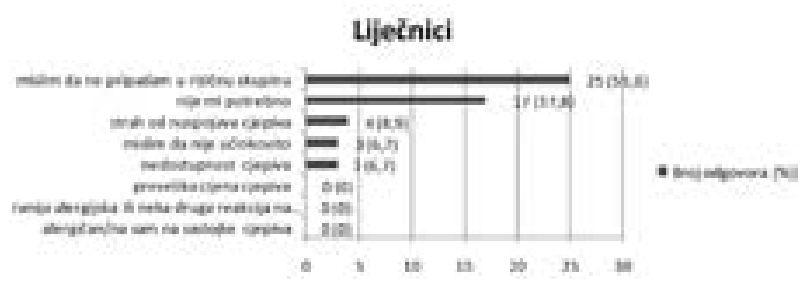

Slika 15. Razlozi za izbjegavanje cijepljenja u liječnika

Najčešći razlog necijepljenja većine medicinskih sestara je navela ne pripadanje u rizičnu skupinu, te da im cijepljenje nije nikako potrebno (slika 16).

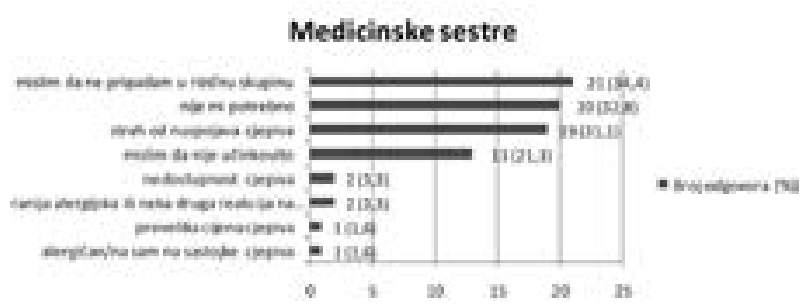

Slika 16. Razlozi za izbjegavanje cijepljenja kod medicinskih sestara 


\section{RASPRAVA}

Ispitanici su očekivano znali u velikom postotku najčešće reakcije nakon cijepljenja jer su se vjerovatno s njima najčešće susretali u svom radu. Najmanje poznata reakcija nakon cijepljenja je bio Guillain-Barreov sindrom, u 33,9 \% ispitanika, što je rijetka reakcija nakon cijepljenja i ostaje činjenica da je povećana učestalost Guillain-Barreovog sindroma dokazana samo tijekom cijepljenja protiv svinjske gripe 1976. godine $(16,17)$.

Lokalne reakcije i otok na mjestu primjene su $\mathrm{u}$ visokom postotku znali i doktori medicine i medicinske sestre, a ostale očekivane reakcije su doktori medicine znali češće od medicinskih sestara, što je logično s obzirom na stupanj edukacije. Do sada nisu rađena slična istraživanja o usporedbi znanja, stava i prakse o cijepljenju protiv influence u zdravstvenih djelatnika, tako da nismo našli odgovarajuće rezultate drugih autora za usporedbu s našim. Veliki broj ispitanika, njih 71,1 \% podrazumjeva da su prioritetne skupine osnovna terapijska indikaciju za cijepljenje protiv influence, a manji broj, njih 23,1\% smatra da su to sve osobe $\geq 6$ mjeseci života ako ne postoje kontraindikacije, iako od 2010. godine u Sjedinjenim Američkim Državama se cijepljenje preporučuje svim osobama starijim od šest mjeseci ako ne postoje kontraindikacije za cijepljenje (7).

Usporedbom odgovora ispitanika s obzirom na radno mjesto, očekivano su zaposlenici Klinike za infektologiju upoznati su s najnovijim smjernicama i preporukama za cijepljenje. Nismo pronašli slična istraživanja o usporedbi ispitanika s obzirom na radno mjesto s kojima bi mi mogli usporediti naše dobivene rezultate. Liječnici i medicinske sestre dobro znaju iz kliničke prakse da je pneumonija najčešća komplikacija influence, virusna ili bakterijska. Međutim, ostale komplikacije influence (otitis media, sinusitis, encefalopatija, akutna egzacerebacija KOPB-a, Guillain-Barreov sindrom, infarkt miokarda, reaktivni artritis, sepsa, te Reyeov sindrom) su ispitanici manje poznavali, od $12,4 \%-46,3 \%$, vjerovatno zbog rijetkosti pojavljivanja u kliničkoj praksi.

Naši ispitanici su dobro upućeni u postojeće preporuke o prijenosu infekcije i dobro znaju da zdravstveni djelatnici imaju veći rizik za profesionalnu izloženost i obolijevanje od influence te kao takvi su potencijalni prenositelji virusa na druge osobe koje borave u zdravstvenim ustanovama (7). Veći broj, njih $61,5 \%$ u odnosu na medicinske sestre, njih $28,4 \%$ smatra cjepivo protiv influence koje se koristi u Federaciji Bosne i Hercegovine sigurnim i pouzdanim. Na pitanja o edukaciji i informiranosti zdravstvenih djelatnika i pacijenata o cjepivu, ispitanici su bili jasni. Većina njih 84,3 \%, smatra da pacijenti nisu dovoljno informirani, a 77,7 \% ispitanika smatra da niti sami zdravstveni djelatnici nisu dovoljno educirani o cjepivu protiv influence. U Italiji je rađeno slično istraživanje među zdravstvenim djelatnicima te su autori zaključili da je jako potrebna edukacija i jasna strategija poboljšanja znanja zdravstvenih djelatnika o influenci i cijepljenju protiv influence (18). Zanimljivo je da medicinske sestre, njih 40,3\%, češće misle da svi zdravstveni djelatnici trebaju biti obvezno cijepljeni protiv influence za razliku od manjeg broja liječnika (njih 23,1 \%).

Veći broj zaposlenika Klinike za infektologiju, njih $87,5 \%$, smatra da svi zdravstveni djelatnici trebaju biti obvezno cijepljeni protiv influence za razliku od drugih kolega koji rade na ostalim ispitivanim odjelima i klinikama. Neki autori smatraju da cijepljenje zdravstvenih djelatnika predstavlja jedan od osnovnih standarda brige prema pacijentu, a necijepljenje zdravstvenih djelatnika nemar prema pacijentima, te da bi kao takvo trebalo biti obavezno (19). Očekivano liječnici, njih $75 \%$, značajno češće savjetuju i promoviraju cijepljenje protiv influence od medicinskih sestara (32,8\%), osobito zaposlenici Klinike za infektologiju, njih $61,1 \%$. Prosječna procijepljenost protiv influence za ovu sezonu ispitanika je bila $14,9 \%$. Liječnici i medicinske sestre Klinike za infektologiju jedini su se cijepili protiv influence za ovu sezonu u odnosu na kolege ostalih ispitivanih klinika i odjela.

Procijepljenost na ispitivanim odjelima, s izuzetkom Klinike za infektologiju, je poražavajuće niska do $5 \%$. Ako ove rezultate usporedimo sa prosjekom klinika i bolnica u Republici Hrvatskoj, možemo vidjeti da su u prosjeku niži jer je u Republici Hrvatskoj u 2007. godini procijepljenost se pojedinih 
skupina bolničkog osoblja u kliničkim ustanovama kretala od $10 \%$ do $90 \%$ s prosječnom procijepljenošću svih radnika od $26 \%$. Pri tome su u nekim klinikama najveće stope procijepljenosti bile među liječnicima (do $90 \%$ ), te medicinskim sestrama (do $47 \%)$. U općim bolnicama prosječna je procijepljenost bila nešto niža ( $23 \%)$ nego u klinikama, a kretala se od $2 \%$ do $59 \%$. Ovdje su stope procijepljenosti zabilježene među liječnicima (do $72 \%$ ) te medicinskim sestrama (do 67 \%). U 2009. je godini zbog pandemije influence i u hrvatskim bolnicama zabilježeno povećanje stope procijepljenosti bolničkog osoblja protiv sezonske influence. U kliničkim i općim bolnicama sveukupna procijepljenost bolničkog osoblja kretala se čak do 59 \% (u općim prosječno $27,3 \%$, a u kliničkim prosječno $28,6 \%$ ). Pri tome je zabilježen i veći udio procijepljenosti pojedinih skupina zaposlenika: liječnika do $87 \%$, medicinskih sestara do $67 \%$ (7).

$\mathrm{U}$ cijepljenju protiv influence proteklih godina, također se izdvajaju doktori medicine, njih $75 \%$, i medicinske sestre, njih 54,5 \% Klinike za infektologiju, dok je kod ostalih taj postotak niži i kreće se od $5,3 \%$ do $18,2 \%$. Kao glavni razlog necijepljenja ispitanici su naveli da ne pripadaju rizičnoj skupini za oboljevanje od influence, njih 42,7 \%, a njih 33,6\% smatra da njima cjepivo nije potrebno. Liječnici su najčešće navodili ova dva razloga kao glavne razloge necijepljenja u omjeru 48,1 \% i 32,7 \%. Medicinske sestre su osim ova dva razloga ( $31,3 \%$ i $29,9 \%)$, navodile i strah od nuspojava cjepiva $(28,4 \%)$. Ovi se razlozi djelomično poklapaju sa studijom u kojoj su uzete u obzir 25 studija o necijepljenju zdravstvenih djelatnika. Glavni razlozi za necijepljenje koje se navode su strah od nuspojava, sumnja u učinkovitost cjepiva, nezabrinutost zbog influence, neadekvatna dostava, te nedostatak percepcije o vlastitom riziku (12).

S obzirom na naše dobivene rezultate slično provedenom istraživanju o cijepljenju zdravstvenih djelatnika protiv influence u Italiji zaključujemo da je među našim zdravstvenim djelatnicima neophodna bolja edukacija o cijepljenju protiv influence i važnosti istoga te napraviti u budućnosti jasnu strategiju u poboljšanja znanja zdravstvenih djelatnika o influenci i cijepljenju protiv influence. Potrebno je uspostaviti u budućnosti jasne i konkretne obrazovne programe s pouzdanim informacijama o cjepivu protiv influence i raditi na podizanju svijesti o korištenju cjepiva najprije među zdravstvenim djelatnicima tako da oni mogu djelovati kao promotori cjepiva među općom populacijom (20). Edukativna kampanja o cijepljenju protiv influence osim prednosti cijepljenja treba sadržavati i razumljive informacije o mogućim štetnim učincima i njihovoj učestalosti te bi se tako nepovjerljivost prema cijepljenju svela na minimum (21).

\section{ZAKLJUČCI}

Prosječna procijepljenost ispitivanih zdravstvenih djelatnika protiv influence je bila niska, a uposlenici Klinike za infektologiju su značajno češće cijepljeni protiv influence proteklih godina te za ovu sezonu. Kao glavne razloge necijepljenja ispitanici su naveli ne pripadanje rizičnoj skupini za oboljevanje od influence te većina njih smatra da njima cjepivo nije potrebno niti da trebaju obvezno biti cijepljeni protiv influence. Osim toga, većina je mišljenja da nisu niti pacijenti niti zdravstveni djelatnici dovoljno informirani o cjepivu protiv influence. Liječnici su statistički značajno češće savjetovali i promovirali cijepljenje protiv influence od medicinskih sestara, jer smatraju za razliku od njih da je cjepivo protiv influence koje se koristi u Federaciji Bosne i Hercegovine sigurno i pouzdano. Veći broj zdravstvenih djelatnika poznaje dobro komplikacije influence, ali ne i indikacije za cijepljenje.

Većina zdravstvenih djelatnika su svjesni izloženosti većem riziku za profesionalnu izloženost i obolijevanje od influence te da su kao takvi potencijalni prenositelji virusa na druge osobe koje borave u zdravstvenim ustanovama. 


\section{LITERATURA}

1. Kuzman I. Virusi influence. U: Kuzman I. Pneumonije - uzročnici, dijagnostika i liječenje. Zagreb: Medicinska naklada 1999;284-97.

2. Puljiz I, Kuzman I. Gripa - uvijek aktualna bolest. Medicus. 2005;14:137-46.

3. Kuzman I. Virusi influence. U: Begovac J, Božinović D, Lisić M i sur. Infektologija. Zagreb: Profil 2006;490-6.

4. Kuzman I. Ptičja gripa i pandemija influence: Očekivana realnost. Infekt Glasnik. 2006;26:2-5.

5. Kunisaki KM, Janoff EN. Influenza in immunosuppressed populations: a review of infection frequency, morbiditiy, mortality and vaccine responses. Lancet Infect Dis. 2009;9:493-504.

6. Nguyen-Van-Tam JS, Openshaw PJ, Hashim A, Gadd EM, Lim WS, Semple MG, i sur. Influenza Clinical Information Network (FLU-CIN). Risk factors for hospitalisation and poor outcome with pandemic A/H1N1 influenza: United Kingdom first wave (May-September 2009) Thorax. 2010;65:645-51.

7. Čivljak R. Zdravstveni radnici i cijepljenje protiv influence. Medicus. 2011;20:115-22.

8. Kaić B. Cijepljenje protiv influence. Medicus. 2011;1:101-8.

9. Carman WF, Elder AG, Wallace LA, McAulay K, Walker A, Murray GD, Stott DJ. Effects of influenza vaccination of health-care workers on mortality of elderly people in long-term care: a randomised controlled trial. Lancet. 2000;355:93-7.

10. Wilde JA, McMillan JA, Serwint J, Butta J, O’Riordan MA, Steinhoff MC. Effectiveness of influenza vaccine in health care professionals: a randomized trial. JAMA. 1999;281:908-13.

11. Bernstein HH, Starke JR. Policy statement-recommendation for mandatory influenza immunization of all health care personnel. Pediatrics. 2010;126:809-15.
12.Hollmeyer HG, Hayden F, Poland G, Buchholz $\mathrm{U}$. Influenza vaccination of health care workers in hospitals-a review of studies on attitudes and predictors. Vaccine. 2009;27:3935-44.

13. Wicker S, Rabenau HF, Doerr HW, Allwinn R. Influenza vaccination compliance among health care workers in a German university hospital. Infection. 2009;37:197-202.

14. Omer SB, Salmon DA, Orenstein WA, de Hart P, Halsey N. Vaccine refusal, mandatory immunization, and the risks of vaccine-preventable diseases. N Engl J Med. 2009;360:1981-8.

15. Poland GA, Tosh P, Jacobson RM. Requiring influenza vaccination for health care workers: seven truths we must accept. Vaccine. 2005;23:2251-5.

16. Haber P, DeStefano F, Angulo FJ, Iskander J, Shadomy SV, Weintraub E i sur. Guillain-Barre syndrome following influenza vaccination. JAMA. 2004;292:2478-81.

17.Lasky T, Terracciano GJ, Magder L, Koski CL, Ballesteros M, Nash D i sur. The Guillain-Barre syndrome and the 1992-1993 and 1993-1994 influenza vaccines. N Engl J Med. 1998;339:1797-802.

18. Albano L, Matuozzo A, Marinelli P, Di Giuseppe G. Knowledge, attitudes and behaviour of hospital health care workers regarding influenza A/ H1N1: a cross sectional survey. BMC Infect Dis. 2014;16:14.

19. Cortes-Penfield N. Mandatory Influenza Vaccination for Health Care Workers as the New Standard of Care: A Matter of Patient Safety and Nonmaleficent Practice. Am J Public Health. 2013 Dec 12.

20. Aguilar-Díaz Fdel C, Jiménez-Corona ME, Ponce-de-León-Rosales S. Influenza vaccine and healthcare workers. Arch Med Res. 2011;42:652-7.

21. Torun SD, Torun F. Vaccination against pandemic influenza $\mathrm{A} / \mathrm{H} 1 \mathrm{~N} 1$ among healthcare workers and reasons for refusing vaccination in Istanbul in last pandemic alert phase. Vaccine. 2010;28:5703-10. 


\title{
KNOWLEDGE, ATTITUDE AND PRACTICE OF HEALTH CARE PROFESSIONALS ABOUT VACCINATION OF HEALTH CARE WORKERS AGAINST INFLUENZA IN THE UNIVERSITY CLINICAL HOSPITAL MOSTAR
}

\author{
${ }^{1}$ Mimica I, ${ }^{2}$ Šegvić O, ${ }^{13}$ Nikolić J, ${ }^{1} 4$ Vasilj I, ${ }^{3}$ Grgić S \\ ${ }^{1}$ Faculty of Medicine, University of Mostar, Bosnia and Herzegovina \\ ${ }^{2}$ Health Center "Dr. Ante Franulovic" Vela Luka, Croatia \\ ${ }^{3}$ Hospital for Infectious Diseases University Clinical Hospital Mostar, Bosnia and Herzegovina \\ 4 Faculty of Health Studies, University of Mostar, Bosnia and Herzegovina
}

\begin{abstract}
INTRODUCTION: Vaccination of health care workers can reduce the transmission of infection to patients who carry a high risk of developing complications, and can reduce the number of deaths associated with influenza. Therefore, the aim of this study was to examine the knowledge, attitude and practices of health care workers in the University Clinical Hospital Mostar on vaccination of health care workers against influenza.

METHODS: Respondents in the survey were doctors and nurses employed at the Clinic for Neurology, Pediatric Clinic, Clinic for Infectious Diseases, Department of Pulmonary Diseases and the Center for Emergency Medicine at the University Clinical Hospital Mostar. In this study we used a questionnaire for the survey of knowledge, attitude and practices of health care professionals about vaccination of health care workers against influenza.

RESULTS: Most of the expected reactions after vaccination, complications of influenza and the issue of the safety of vaccines against influenza, medical doctors knew significantly more than nurses. Medical doctors employed at the Clinic for Infectious Diseases were significantly more familiar with the most of the possible complications after vaccination and indications for influenza vaccination than the other colleagues. Nurses, opposed to medical doctors, significantly more often thought that all health care workers should be mandatory vaccinated against influenza. Unlike their colleagues, doctors of the Clinic for Infectious Diseases significantly more often considered that all health care workers should be mandatory vaccinated against influenza. Medical doctors were significantly more likely to advise and promote vaccination against influenza than nurses.

CONCLUSION: The average immunization coverage against influenza among health care workers at the University Clinical Hospital Mostar was low, their attitudes negative and knowledge about influenza and vaccination against influenza inadequate.
\end{abstract}

Keywords: Influenza, knowledge, attitude, vaccination, health workers, physicians, nurses.

Correspondence:

Svetlana Grgic, MD. MSc

Clinic for Infectious Diseases

University Clinical Hospital Mostar

svjetlanag@gmail.com

Phone No. 0038763790032

63317314 